\title{
COVID-19'a Yönelik Bilgi, Tutum ve Davranış Ölçeğinin Türkçe Geçerlik ve Güvenirlik Çalışması
}

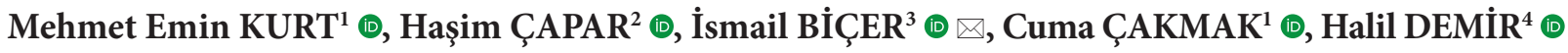 \\ ${ }^{1}$ Dicle Üniversitesi, İktisadi ve İdari Bilimler Fakültesi, Sağlık Yönetimi Bölümü, Diyarbakır, Türkiye \\ ${ }^{2}$ İstanbul Sabahattin Zaim Üniversitesi, Sağlık Bilimleri Fakültesi, Sağlık Yönetimi Bölümü, İstanbul, Türkiye \\ ${ }^{3}$ Pamukkale Üniversitesi, Çivril Atasay Kamer Meslek Yüksekokulu, Sağlık Kurumları İşletmeciliği Programı, Denizli, Türkiye \\ ${ }^{4}$ İstanbul Rumeli Üniversitesi, Sağlık Hizmetleri Meslek Yüksekokulu, Tıbbi Dokümantasyon ve Sekreterlik Programı, İstanbul, Türkiye \\ Bu makaleye yapılacak atıf: Kurt ME, Çapar H, Biçer İ, Çakmak C, Demir H. COVID-19’a Yönelik Bilgi, Tutum ve Davranıș Ölçeğinin Türkçe Geçerlik ve Güvenirlik Çalışması. \\ Turk J Diab Obes 2021;1: 43-50.
}

\begin{abstract}
ÖZ
Amaç: Bu çalışmanın amacı, Zhong ve arkadaşları tarafından geliştirilen COVID-19’a Yönelik Bilgi, Tutum ve Davranış Ölçeğinin Türkçe geçerlik ve güvenirlik analizlerini gerçekleştirmektir.

Gereç ve Yöntemler: Ölçeğin geçerlik çalışmaları için açımlayıcı faktör analizi, güvenirlik çalışmaları için ise iç tutarlılık analizleri yapılmıştır. FACTOR Yazılım Programı ile Temel Bileşenler Analizi ve Normalize Varimax Rotasyon Yöntemi ile veriler analiz edilmiştir. Değişkenlerin aldığı cevaplar 0 ile 1 arasında değiştiğinden Polikorik Faktör Analizi yürütülmüştür. Öz değeri 1 ve üzeri olan bileşenler faktör olarak kabul edilmiştir. Ayrıca Doğrulayıcı Faktör Analizi (DFA) ile orijinal ölçeğin yapısı doğrulanmıştır.

Bulgular: Elde edilen bulgulara göre, orijinal ölçek, 5 faktör ve 16 maddeden oluşmaktadır. Açımlayıcı Faktör Analizi (AFA) sonuçlarına göre ortaya çıkan beş boyutlu yapı, toplam varyansın \% 60,208'ini açıklamaktadır. Güvenirlik analizi için bakılan Cronbach Alpha değerleri faktörler için 0,785- 0,712 arasında değişmektedir. DFA sonuçlarına göre; $\chi 2$ değerinin istatistiksel olarak anlamlı olduğu ( $\chi 2 /$ $s d=2,840 ; p<0,001$ ), yine DFA analizinde bakılan önemli diğer uyum iyiliği değerlerinden RMSEA=0,004; GFI=0,920; AGFI=0,940; $\mathrm{CFI}=0,952$; NFI=0,912; TLI=0,919; IFI=0,909 olarak tespit edilmiş olup modelle ilgili uyum değerlerinin üç faktörlü yapının iyi orijinal çalışma ile uyum gösterdiği görülmüştür.

Sonuç: Gerçekleştirilen bu çalışma ile literatüre geçerli ve güvenilir bir ölçek kazandırıldığı düşünülmektedir. Bu çalışmanın gelecekteki araştırmalara referans olabileceği ve toplumda COVID-19’a yönelik mevcut bilgi, tutum ve davranış düzeyinin ölçülmesinde önemli bir araç olabileceği düşünülmektedir.
\end{abstract}

Anahtar Sözcükler: Geçerlik, Güvenirlik, Bilgi, Tutum ve davranışölçümü, COVID-19

\section{Turkish Validity and Reliability Study of Knowledge, Attitude, and Behavior Scale Towards COVID-19}

\begin{abstract}
Aim: The aim of this study is to perform the Turkish validity and reliability analysis of the Knowledge, Attitude and Behavior Scale for COVID-19 developed by Zhong et al.

Material and Methods: Exploratory factor analysis was performed for validity studies of the scale, and internal consistency analysis was performed for reliability studies. Data were analyzed with FACTOR Software, Basic Components Analysis, and Normalized Varimax Rotation Method. Since the answers received by the variables ranged between 0 and 1, Polycric Factor Analysis was conducted. Components with an eigenvalue of 1 and above were accepted as factors. In addition, the structure of the original scale is verified with Confirmatory Factor Analysis (CFA).
\end{abstract}

ORCID: Mehmet Emin Kurt / 0000-0002-7181-8681, Haşim Çapar / 0000-0001-7056-7879, İsmail Biçer / 0000-0003-1878-0546, Cuma Çakmak / 0000-0002-4409-9669, Halil Demir / 0000-0001-9374-9739 
Results: According to the findings, the original scale consists of 5 factors and 16 items. The five-dimensional structure emerging according to the Explanatory Factor Analysis (EFA) results explains $60.208 \%$ of the total variance. Cronbach's alpha values checked for reliability analysis ranged from 0.785 to 0.712 for factors. According to CFA results; the value of $\chi 2$ was statistically significant ( $\chi 2$ / $\mathrm{df}$ $=2,840 ; \mathrm{p}<0.001)$. Another important goodness of fit values examined in the CFA analysis are RMSEA $=0.004 ; \mathrm{GFI}=0.920 ; \mathrm{AGFI}=$ 0.940 ; $\mathrm{CFI}=0.952 ; \mathrm{NFI}=0.912$; $\mathrm{TLI}=0.919, \mathrm{IFI}=0.909$. It was observed that the three-factor structure showed good fit for the original model-related fit values.

Conclusion: It is thought that with this study, a valid and reliable scale has been brought to the literature. It is thought that this study can be a reference for future research and can be an important tool in measuring the current level of knowledge, attitude, and behavior towards COVID-19 in the society.

Key Words: Validity, Reliability, Measurement of knowledge, Attitude and behavior, COVID-19

\section{GíRiș}

Koronavirüsler (CoV) ailesi, toplumda soğuk algınlığı belirtisi gibi yaygın görülmenin yanında, Ağır Akut Solunum Sendromu (Severe Acute Respiratory Syndrome, SARS) ve Orta Doğu Solunum Sendromu (Middle East Respiratory Syndrome, MERS) gibi çok daha ciddi klinik sonuçlara neden olabilen geniş kapsamlı bir virüs ailesidir. CoV’ların insanlarda bulunup, insandan insana kolaylıkla bulaşabilen çeşitli alt tipleri (HCoV-229E, HCoV-OC43, HCoV-NL63 ve HKU1-CoV) mevcut olup çoğunlukla soğuk algınlığına sebep olmakta iken hayvanlarda saptanıp insanlara geçerek çok ağır hastalık tablolarına neden olan türlerinin olduğu da bilinmektedir. Dünya Sağlik Örgütü (DSÖ) tarafından 31 Aralık 2019'da, Çin'in Hubei eyaletinin Wuhan şehrinde etiyolojik durumu bilinmeyen pnömoni vakalarının arttığ insanlarda tespit edilmemiş olan yeni bir koronavirüs türü (2019- nCoV) olduğu ifade edilmiştir. Sonrasında ise 2019nCoV hastalığının adı COVID-19 olarak kabul edilmiştir. DSÖ 30 Ocak'ta tüm dünya ülkeleri için COVID-19 salgınının önemli bir halk sağlığı acil durumu olduğunu belirtmiş ve salgının ilk ortaya çıktığı Çin dışında 113 ülkede virüs kaynaklı vakaların görülmeye başlanması nedeniyle yeni durumu pandemi olarak tanımlamıştır. Ülkemizde ise COVID-19 ile ilgili çalışmalar Sağlık Bakanlığı nezdinde 10 Ocak 2020'de başlatılmış olup 22 Ocak'ta Bakanlık Bilimsel Danışma Kurulu ilk toplantısını gerçekleştirmiş, alınan önlemler ile ilk COVID-19 vakası 11 Mart 2020'de görülmüştür (1).

Sağlık Bakanlığı Bilimsel Danışma Kurulunun halk sağlığını önceleyen kararları doğrultusunda ülkemiz çapında öncelikle ilk-orta-lise ve üniversitelerde ikinci bir emre kadar eğitim-öğretime ara verilir iken devamında hafta sonları ile resmi tatiller ve beraberinde gelen ramazan bayramı tatil günlerini kapsayacak şekillerde sokağa çıkma yasağı uygulamaları getirilmiş olup bunun yanında diğer günler için toplu ulaşım araçlarında kısıtlama ve doluluk oranları düşürülmüş, berberler, lokantalar, sinema salonu ve alışveriş merkezlerini kapsayacak şekilde tüm sosyal yaşamın olduğu mekânlar kapatılmıştır. Devamında hızlı sonuçlar veren virüs tanı kitleri hızlıca ülke çapında dağıtılmaya başlanmış, yurtdışından gelen veya getirilen vakalar öğrencilerden boşalan yurtlara 14 günlük karantina kapsamında izlemeye alınmış, vatandaşların şikâyetleri kapsamında "ALO 184 Korona Danışma Hattı” kurulmuş, kademeli olarak pek çok ülkeye uçuş yasakları konulmuştur ve en önemlisi de tüm ülkede vatandaşların maske takmasının zorunlu hâle getirilmesi bununla birlikte bilim kurulunun önerileri doğrultusunda mesken dışında sosyalleşmenin gerçekleştirildiği alanlarda sosyal mesafenin nasıl olması gerektiği ve bireysel hijyen uygulamalarının nasıl ve hangi yöntemlerle sağlanacağına dair bilgilendirmeler yapılmıştır. COVID-19 vakasına karşın savaş, tüm ülkelerde olduğu gibi Türkiye'de de yukarıda belirtilen halk sağlığı önlemleri ile devam etmektedir. Sağlığın korunması, geliştirilmesi ve toplumda virüse karşı oluşan panik havasının ortadan kaldırılması noktasında oluşturulan eylem planlarına uymak salgının yayılımını engelleyecek önemli bir güçtür.

Nihai başarıların elde edilebilmesi için insanların mevcut kontrol önlemlerine bağlılıkları esas olup hastalığa karşın bilgi, tutum ve davranışları da bu başarıya büyük ölçüde katkı sunacaktır (2,3). 2003’teki SARS salgını şunu göstermektedir ki; bulaşıcı hastalıklara yönelik bilgi ve tutumlar, popülasyondaki panik düzeyiyle ilişkilidir. Bu durum hastalığın yayılmasını önleme girişimlerini daha da karmaşık hale getirmektedir. Toplumlarda veya belirli topluluklarda salgın hastalıklarla gelișen belirsizlikler nedeniyle hastalık ve ölüm korkusu önemli ölçüde korku ve panik oluşmasına neden olabilir. Enfekte olmuş veya teması olan kişilere yönelik korkuların ve ayrımcılıkların azaltılması, toplum içinde bulaşmayı kontrol etmede önemli etkilere sahiptir $(4,5)$. Zira korkutulan ve damgalanan kişiler, yardım aramayı geciktirebilir ve fark edilmeden toplumda kalarak salgının ilerlemesini etkileyebilir.

Çalışmanın amacı, Zhong ve ark. (6) tarafından geliştirilen COVID-19’a Yönelik Bilgi, Tutum ve Davranış Ölçeğinin 
Türkçe geçerlik ve güvenirlik analizlerini yaparak COVID-19 hastalığına ilişkin bilimsel çalışmalara referans olabilecek Türkçe uyarlaması yapılan bir ölçek kazandırmaktır.

Bilgi, tutum ve davranış değişiklikleri halk sağlığı bakış açısı ile hastalıkların oluşma ihtimallerine karşın, hastalıkların oluşma öncesinde bireylerde istenen ve beklenen kalıcı koruma/korunma önlemlerinin, hayatın doğal akışı içerisinde bilinmesi ve uygulanmasını kapsamaktadır. Hastalıklar hakkında bireylerin bilgi, tutum ve davranışlarını belirlemek bize, hastalıklara karşı bireylerin bilgi düzeylerinin değerlendirilmesinin yapılıp odak konu hakkında tutum ve davranış değişikliklerinin sağlanmasında daha iyi uygulamalar için rehber özelliği oluşturma zemini sağlar.

Sağlık başta olmak üzere tüm alanlarda bireylerin herhangi bir konu hakkında bilgi, tutum ve davranışlarını belirlemeye yönelik oluşturulan sorular ortak bir mantıkla bireylerin o konu hakkında bilgi sahibi olup olmadıklarını, mevcut bilgileri elde etme kanallarını, elde edilen bilgilerin kendilerinde gerçekleştirip/gerçekleştiremediği tutumlarını ve en sondada elde edilen bu bilgi ve tutumların kendilerinin mevcut yaşamlarında herhangi bir davranış değişikliklerine yol açıp açmadığını kapsamaktadır.

Hastalığa yönelik toplumun sağlıklı kaynaklar üzerinden bilgi, tutum ve davranıșları belirlenerek, bu bilgi, tutum ve davranışları etkileyebilecek nedenlerin ortaya konulması ve elde edilen sonuçlar ile yapılacak çalışmalara yardımcı olacak dolayısı ile hastalık hakkında bireyde istenen davranıs değişikliklerine yol açıcı zemini yaratacaktır (7).

\section{GEREÇ ve YÖNTEMLER}

\section{Çalışmanın Amacı ve Önemi}

Çalışmanın amacı, Zhong ve arkadaşları tarafından geliștirilen COVID-19’a Yönelik Bilgi, Tutum ve Davranış Ölçeğinin (6) Türkçe geçerlik ve güvenirlik analizlerini yaparak, COVID-19 hastalığına ilişkin bilimsel çalışmalara referans olabilecek ve toplumda hastalığa ilişkin bireysel anlamda bilgi, tutum ve davranışı ölçmeye yönelik Türkçe uyarlaması yapılan bir ölçek kazandırmaktır. Ayrıca Doğrulayıcı Faktör Analizi (DFA) ile orijinal ölçeğin yapısı doğrulanmıştır.

\section{Araştırmanın Evren ve Örneklemi}

Araştırmada örneklem seçimine gidilmemiş olup pandemi nedeniyle çevrimiçi olarak anket uygulaması yapılmıştır. Ulaşılabilecek maksimum sayıda katılımcıya ulaşılmak istenmiştir. Araştırma kapsamında 860 katılımcıya ulaşılmıştir.

\section{Araștırmanın Etik Yönü}

Tüm elektronik iletişim kaynaklarından faydalanılarak, katılımcılara, öncelikle araştırmaya katılıp katılmamaları konusunda özgür oldukları ve katılım noktasında kendilerine ait bilgilerin bilimsel araştırmalar dışında başka bir amaçla kullanılmayacağı belirtilmiştir. Araştırmada Sağlık Bakanlığ Bilimsel Araştırma Platformundan ve İstanbul Arel Üniversitesi Girişimsel Olmayan Etik Kurulundan 09.07.2020 tarih ve 2020/04 sayı ile etik kurul onayı alınmıştır. Araştırma 15 Temmuz-15 Ağustos tarihleri arasında gerçekleştirilmiștir.

\section{Çalışmanın Tipi ve İstatistiksel Analizler}

$\mathrm{Bu}$ çalışma, tanımlayıcı, kesitsel ve metodolojik olarak planlanmıştır. Zhong ve ark. tarafından geliştirilen 16 maddelik “COVID-19'a Yönelik Bilgi, Tutum ve Davranış Ölçeği”(6) için Açımlayıcı Faktör Analizi kullanılmıștır. Veriler FACTOR Yazılım Programı ile Temel Bileşenler Analizi ve Normalize Varimax Rotasyon Yöntemi ile analiz edilmiştir. Değişkenlerin aldığ cevaplar 0 ile 1 arasında değiştiğinden Polikorik Faktör Analizi yürütülmüştür. Öz değeri 1 ve üzeri olan bileşenler faktör olarak kabul edilmiştir.

\section{Veri Toplama Araçları}

Bu çalışmada veri toplama aracı olarak anket kullanılmıştır. Kullanılan anket formu, yazarlar tarafindan hazırlanan sekiz soruluk demografik değişkenler ile Zhong ve ark. tarafindan geliştirilen 16 maddelik "COVID-19'a Yönelik Bilgi, Tutum ve Davranış Ölçeği” olmak üzere iki bölümden oluşmaktadır (6). Demografik değişkenler: yaş, cinsiyet, medeni durum, eğitim, gelir, yaşanılan bölge, COVID-19 tanısı alma durumu, yakınlarından birinin COVID-19 tanısı alma durumu olmak üzere toplam sekiz sorudan oluşmaktadır. Ölçeğin bir parçası olan ancak geçerlik ve güvenirlik çalışmasında puanlamaya dâhil edilmeyen COVID-19 tutumu ile ilgili iki soru, COVID-19 uygulaması ile ilgili de iki soru olmak üzere toplamda 4 sorudan oluşan bir bölüm mevcuttur. COVID-19'a Yönelik Bilgi, Tutum ve Davranış Ölçeği, Klinik Sunumlar faktörü (K1-K4, Tablo 1), Bulașma Yolları faktörü (K5-K7, Tablo 1) ile Önleme ve Kontrol faktörü (K8-K12, Tablo 1) olmak üzere üç faktörden oluşmaktadır. Ölçek soruları doğru, yanlış ve bilmiyorum seçeneklerinden oluşmaktadır. Buna göre "doğru" cevapları için 1 puan verildi, "yanlış" ve "bilmiyorum" cevapları için ise 0 puan verildi. Toplam ölçek skoru en düşük 0, en yüksek 12 olabilir. Yüksek puanlar, COVID-19'a yönelik yüksek bilgiye sahip olunduğunu, düşük puanlar ise düşük bilgiye sahip olduğunu göstermektedir. COVID-19'a yönelik tutumlar ile ilgili iki soru (A1-A2, Tablo 1) ve COVID-19 davranışı hakkında iki soru (P1-P2, Tablo 1) olmak üzere dört soru sorulmuştur. 
Tablo 1: COVID-19’a Yönelik Bilgi, Tutum ve Davranış Ölçeği Açıklayıcı Faktör Analizi Sonuçları

\begin{tabular}{|c|c|c|c|c|}
\hline Faktörler & Yükler & $\begin{array}{c}\text { Öz } \\
\text { değerler }\end{array}$ & $\begin{array}{c}\text { Açılklanan } \\
\text { Varyans }\end{array}$ & Seçenekler \\
\hline Faktör 1: Kinik Sunumlar & & 3,285 & 27,381 & \\
\hline
\end{tabular}

K1: COVID-19'un ana klinik semptomları ateş, yorgunluk, kuru öksürük ve kas ağrısıdır.

0,730

Doğru, Yanlış, Bilmiyorum

K2: COVID-19 virüsü olan kişilerde soğuk algınlığının aksine, burun tıkanıklığı, burun akıntısı ve hapşırma

Doğru, Yanlış, Bilmiyorum daha az görülür.

K3: Şu anda COVID-19 için etkili bir tedavi yoktur, ancak erken semptomatik ve destekleyici tedavi çoğu hastanın enfeksiyondan kurtulmasına yardımcı olabilir.

Doğru, Yanlış, Bilmiyorum

K4: Çoğu hastada COVID-19 ağır bir seyir göstermemektedir. Sadece yaşlı, kronik hastalığı olan ve obezlerde daha ciddi bir hastalık seyri göstermesi

Doğru, Yanlış, Bilmiyorum olasidir.

\section{Faktör 2: Bulaşma Yolları}

\section{$2,182 \quad 18,184$}

K5: COVID-19 virüsüne, yabani hayvanları yemek veya yabani hayvanlara temas etmek neden olur.

Doğru, Yanlış, Bilmiyorum

K6: COVID-19 tanısı alan kişiler, ateş olmadığında virüsü başkalarına bulaştıramaz.

Doğru, Yanlış, Bilmiyorum

K7: COVID-19 virüsü, enfekte bireylerin solunum yolu damlacıkları ile yayılır.

0,720

Doğru, Yanlış, Bilmiyorum

\section{Faktör 3: Önleme ve Kontrol}

K8: İnsanlar, COVID-19 virüsünün bulaşmasını önlemek için genel tıbbi maskeler takabilirler.

K9: COVID-19 virüsünün bulaşmasını önlemek için çocuklar ve yetişkinlerin önlem almaları gerekli değildir.

K10: COVID-19 enfeksiyonunu önlemek için, insanlar, tren istasyonları gibi kalabalık yerlere gitmek ve toplu taşıma araçlarını kullanmaktan kaçınmalıdır.

$1,757 \quad 14,643$

Doğtu, Yanlis, Bilmiyorum

K11: COVID-19 tanısı almış kişilerin izole ve tedavi edilmesi, virüsün yayılmasını azaltmada etkili bir 0,766

Doğru, Yanlış, Bilmiyorum yöntemdir.

0,751

Doğru, Yanlış, Bilmiyorum

K12: COVID-19 virüsü bulaşmı̧ biriyle temas eden

kişilerin derhal uygun bir yerde izole edilmesi ve 14 gün $\quad 0,894$

Doğru, Yanlış, Bilmiyorum süre ile gözlem altına alınması gerekir.

\section{Faktör 4: Tutumlar}

A1: COVID-19'un, başarıyla kontrol altına alınabileceği

konusunda hemfikir misiniz?

Doğru, Yanlış, Bilmiyorum

A2: Türkiye'nin COVID-19 virüsüne karşı verdiği savaşı kazanabileceğine inanıyor musunuz?

Doğru, Yanlış, Bilmiyorum

Faktör 5: Davranış

P1: Son günlerde kalabalık bir yere gittiniz mi?

Evet, hayır

P2: Son günlerde, evden ayrilırken maske taktınız mı?

Evet, hayır

Kaiser -Meyer-Olkin: 0,812

Barlett Küresellik Testi Ki Kare: 9822,4

$p<0,001$

Açıklanan Toplam Varyans: 60,208

Faktör 4 ve Faktör 5 Faktör analizine dâhil edilmediğinden faktör yükleri, öz değerleri ve açıklanan varyansları verilmemiştir. 


\section{BULGULAR}

\section{Tanımlayıcı Bulgular}

Bu çalışmaya katılanların \% 66,4’ü ( $\mathrm{n}=571)$ kadın, \% 33,6'sı $(n=289)$ ise erkektir. Araştırmaya katılanların yaş ortalamasi ve standart sapması $29,35 \pm 10,236$ 'dır. Katılımciların \% 62,9'u (n=541) bekâr, \% 34,1'i $(n=293)$ evli ve \% 3,0'ü $(\mathrm{n}=26)$ ise boşanmıştır. Katılımcıların eğitim durumuna bakıldığında; \% 4,9’u ( $\mathrm{n}=42)$ ilkokul, \% 31,5’i $(\mathrm{n}=271)$ lise, \% 26's1 ( $\mathrm{n}=224)$ ön lisans, \% 26's1 $(\mathrm{n}=224)$ ise lisans ve \% $11,5$ ’ ( $n=99)$ lisansüstü eğitim seviyesine sahip olduğu görüldü. Katılımcıların toplam hane gelirleri minimum 1.000 TL, maksimumu 35.000 TL'dir. Katılımcıların yaşadığı bölgelere bakıldığında; katılanların \% 3,4'ü (n=29) Akdeniz, \% 26,3'ü ( $\mathrm{n}=226)$ İç Anadolu, \% 52'si ( $\mathrm{n}=447)$ Marmara, \% 2,4'ü $(n=21)$ Ege, \% 3,1'i $(n=27)$ Karadeniz, \% 9,5'i $(n=82)$ Güneydoğu Anadolu, \% 3,3’ü (n=28) ise Doğu Anadolu bölgesinde yaşadığ görülmektedir. Katılımcıların hiç birine COVID-19 teşhisinin konulmadığ Buna karşın katılımcıların \% 17,4'ü $(\mathrm{n}=150)$ yakınlarına COVID-19 teşhisi konulduğunu, öte yandan \% 82,6'sının $(\mathrm{n}=710)$ ise yakınlarına COVID-19 teşhisinin konulmadığını ifade etmiştir.

\section{Geçerliğe İlişkin Bulgular}

\section{Dil Geçerliği}

COVID-19'a Yönelik Bilgi, Tutum ve Davranış Ölçeği, Zhong ve ark. tarafından İngilizce dili ile geliştirilmiş bir ölçektir (6). Bu ölçeğin Türkçe geçerlik ve güvenirlik çalışması için öncelikle 16 maddelik İngilizce olan orijinal ölçek İngiliz dilini, yapısını bilen bir akademisyen tarafından Türkçe'ye çevrilmiştir. Daha sonra başka bir akademisyen tarafından Türkçe'ye çevrilmiş olan maddeler tekrar İngilizce'ye çevrilmiş son olarak hem Türkçe hem de İngilizce dil yapısını bilen bir akademisyen tarafından ölçek, tekrar Türkçe'ye çevrilmiştir. Türkçe'ye çevrilen ölçek, COVID-19 konusunda çalışmalar yürüten dört akademisyen tarafından bazı kavramlar, uygun ve anlaşlır hâle getirilerek ölçeğe son şekli verilmiştir.

\section{Yapısal Geçerlik}

COVID-19'a Yönelik Bilgi, Tutum ve Davranış Ölçeği yapı geçerliliği için Açıklayıcı Faktör Analizi (AFA) yürütülmüştür $(8,9)$. Açıklayıcı Faktör Analizi (AFA), herhangi bir konu hakkında oluşturulmuş bir havuzundaki her bir maddenin yüklendiği faktörleri tespit etmek ve faktörlerin yüklerine ilişkin açıklayıcı bilgiler sunmak amacı ile gerçekleştirilmektedir (10). Tavşancıl (2006) AFA'nın yürütülebilmesinde gerekli örneklem sayısının kullanılan ölçek maddelerinin minimum beş katı olması gerektiği ifade etmiştir. AFA'nın uygunluğu Kaiser-Meyer-Olkin (KMO) örneklem yeterlilik testi ile Barlett'in Küresellik Testi sonuçları ile açılanmaktadır. KMO değerinin 0,60 ve üstü olması AFA'nın yürütülebilmesi için yeterli görülmektedir (11).

COVID-19'a Yönelik Bilgi, Tutum ve Davranış Ölçeği, 16 maddeden oluşmaktadır. Bu kapsamda toplanan veriler 860 kişilik bir örneklem ile yürütülmüş böylece AFA için önemli olan bu varsayım karşılanmıştır. AFA, Temel Bileşenler Analizi (TBA) tekniği ve Normalize Varimax rotasyon metodu kullanılarak FACTOR Paket Programı ile yürütülmüştür.

Bu çalışma kapsamında yapılan AFA sonuçları varsayımları çerçevesinde bulunan KMO değeri 0,812 olarak tespit edilmiş olup tavsiye edilen değerin $(0,60)$ üzerindedir. Ayrıca Barlett Küresellik Testi sonucu istatistiksel olarak anlamlı$\operatorname{dir}(\mathrm{p}<, 001)$.

AFA sonucunda ölçekte yer alan 16 maddenin sadece 12 maddesi analize dâhil edilmiştir. COVID-19'a Yönelik Bilgi, Tutum ve Davranış Ölçeği'nin toplamda 3 faktör altında toplandığ 1 tespit edildi. AFA sonuçlarına göre; Zhong ve ark. tarafında geliştirilen COVID-19'a Yönelik Bilgi, Tutum ve Davranış Ölçeği yapısı (6) ile bu çalışma ile elde edilen yapı benzerlik göstermiştir. Her ne kadar birinci madde ile altıncı maddenin, hem birinci faktöre hem de ikinci faktöre yüklendiği görülse de birinci maddenin teorik olarak birinci faktör altında toplanması beklentisi ve birinci faktöre yüksek yüklenme değeri göz önüne alındığında birinci maddenin birinci faktörün altında kalmasına karar verilmiştir. Aynı şekilde altıncı maddenin de ikinci faktöre yüksek yük ile yüklenmiş olması ve bilimsel gerekçelerle altıncı maddenin de ikinci faktör altında kalması gerektiğine karar verilmiştir.

FACTOR programı ile yapılan analizlere ilişkin AFA sonuçları Tablo 1'de verilmiştir. Tablo 1, incelendiğinde maddelere ilişkin faktör yüklerinin 0,679 ile 0,894 arasında değiştiği görülmektedir. Genel olarak faktör yüklerinin eşik değer olarak kabul edilen 0,50'nin üzerinde olması gerektiği ifade edilmektedir (12).

AFA sonuçlarının yapısal anlamda test edildiği bir diğer yapısal geçerlilik analizi ise Doğrulayıcı Faktör Analizidir (DFA). Doğrulayıcı Faktör Analizi (DFA) mevcut veri toplama aracının farklı durumlarda kullanılma durumunu ve AFA ile ortaya çıkan yapısal durumun sağlamasını yapmaktadır (13). Bu çalışma için DFA sonuçları, STATA 14.0 Paket Programı ile elde edilmiştir. DFA için daha önce AFA ile tespit edilmiş olan 12 madde 3 faktörlü yapı modele dâhil edilmiştir. Tablo 2, bu çalışma için yürütülmüş olan DFA'ya ilişkin sonuçları göstermektedir. DFA sonuçlarına ilişkin Tablo 2, incelendiğinde; $\chi 2$ değerinin istatistiksel olarak anlamlı olduğu $(\chi 2 / s d=2,840 ; p<0,001)$ görülmüştür. Yine 
DFA analizinde bakılan önemli diğer uyum iyiliği değerlerinden $\mathrm{RMSEA}=0,004 ; \mathrm{GFI}=0,920 ; \mathrm{AGFI}=0,940 ; \mathrm{CFI}=0,952$; $\mathrm{NFI}=0,912$; TLI=0,919; $\mathrm{IFI}=0,909$ olarak tespit edilmiş olup modelle ilgili uyum değerlerinin üç faktörlü yapının orijinal ölçek ile benzer uyum gösterdiği görülmüştür. Ayrıca modele ilişkin doğrulayıcı faktör analizi yol diyagramı ve faktör yükleri Şekil 1'de gösterilmiştir.

\section{Güvenirliğe İlişkin Bulgular}

COVID-19’a Yönelik Bilgi, Tutum ve Davranış Ölçeği ilişkin güvenirlik analizi kapsamında Cronbach Alpha Katsayısı kullanılmıștır. Analiz kapsamında beş faktör altında toplanan COVID-19'a Yönelik Bilgi, Tutum ve Davranış Ölçeğinin her bir alt boyutu ve ölçek genel güvenirlik katsayıları Tablo 2'de verilmiştir. Ayrıca Tablo 3'de ölçeğin dağı-

Tablo 2: COVID-19’a Yönelik Bilgi, Tutum ve Uygulama Ölçeği Doğrulayıcı Faktör Analizi Sonuçları

\begin{tabular}{lcc}
\hline Uyum İndeksleri & İndeks Değerleri & Referans Değerler \\
\hline$\chi^{2 / s d}$ & 2,840 & $\leq 5$ \\
$\mathrm{p}$ & $<0,001$ & \\
\hline Hata Tahminlerinin Kareköklerinin Ortalaması (RMSEA) & 0,004 & $\leq 0,10$ \\
\hline Uyum İyiliği İndeksi (GFI) & 0,920 & $\geq 0,90$ \\
\hline Düzeltilmiş Uyum İyiliği İndeksi (AGFI) & 0,940 & $\geq 0,90$ \\
\hline Karşılaştırmalı Uyum İndeksi (CFI) & 0,952 & $\geq 0,90$ \\
\hline Normlanmış Uyum İndeksi (NFI) & 0,912 & $\geq 0,90$ \\
\hline Tucker-Lewis İndeksi(TLI) & 0,919 & $\geq 0,95$ \\
\hline Fazlalık Uyum İndeksi (IFI) & 0,909 & $\geq 0,90$ \\
\hline
\end{tabular}

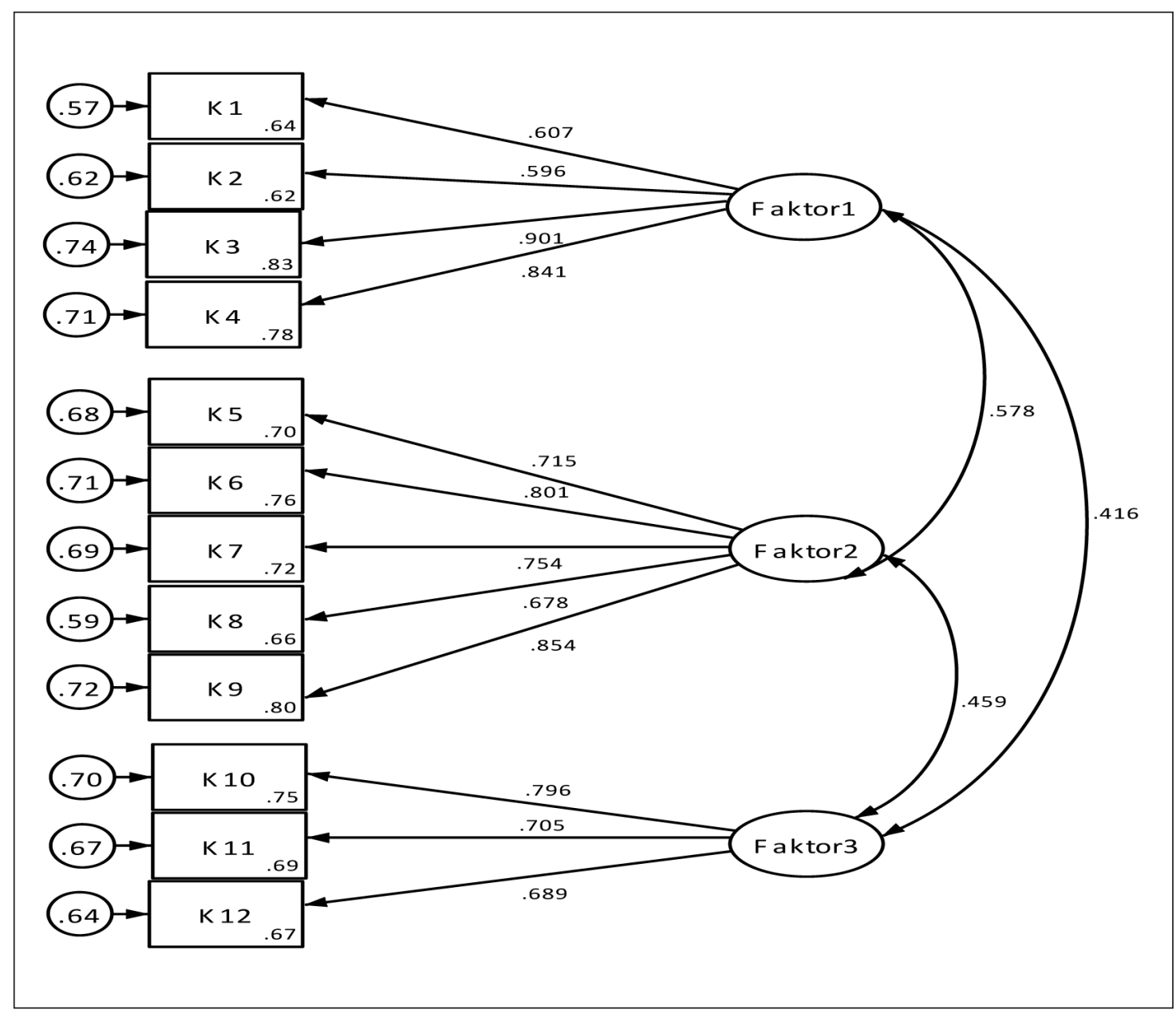

Şekil 1. Doğrulayıcı Faktör Analizi Model Görüntüsü 
Tablo 3: COVID-19’a Yönelik Bilgi, Tutum ve Davranış Ölçeğine İlişkin Güvenirlik ve Normal Dağılıma İlişkin Değerler

\begin{tabular}{lcc}
\hline Faktörler & Cronbach Alpha Değeri & Skewness-Kurtosis \\
\hline Faktör 1: Klinik Sunumlar & 0,785 & $7,513-10,128$ \\
\hline Faktör 2: Bulaşma Yolları & 0,782 & $12,039-21,521$ \\
\hline Faktör 3: Önleme ve Kontrol & 0,734 & $1,185-1,053$ \\
\hline Faktör 4: Tutumlar & 0,712 & $8,219-3,101$ \\
\hline Faktör 5: Davranış & 0,723 & $21,230-15,369$ \\
\hline COVID-19’a Yönelik Bilgi, Tutum ve Davranış Ölçeği & 0,747 & $9,263-11,844$ \\
\hline
\end{tabular}

lımına ilişkin skewness ve kurtosis değerleri de yer almaktadır. Literatüre göre normal dağılım için bakılan önemli iki değerin skewness (çarpıklık) ve kurtosis (basıklık) olduğu bu değerlerin $-1,5$ ile $+1,5$ arasinda olması durumunda verinin normal dağılıma uygun olduğu kabul edilmektedir (14). Buna göre bu çalışmadaki değişkenler polikorik olduğundan skewness (çarpıklık) ve kurtosis (basıklık) değerlerinin normal dağılım göstermemesi beklenir.

\section{TARTISSMA}

Son zamanlarda en çok COVID-19 konusu ile ilgili çalışmalar yapılmaktadır. Bu çalışmaların çoğu da tanımlayıcı ve klinik randomize kontrollü deneyler şeklinde yapılmaktadır. Bu çalışma ise tanımlayıcı, kesitsel ve metodolojik tipte tasarlanmıştır. Buna göre; bu çalışmanın amacı, orijinal dili İngilizce ve polikorik tipinde ( $1=$ doğru; $0=$ yanlış/ bilmiyorum) ile hazırlanmış olan 16 maddelik COVID-19'a Yönelik Bilgi, Tutum ve Davranış Ölçeğinin Türkçe geçerlik ve güvenirlik analizini yaparak Türkçe literatüre kazandırmaktır. Bu amaç kapsamında öncelikle COVID-19'a Yönelik Bilgi, Tutum ve Davranış Ölçeğinin Türkçe dil geçerliği için İngilizce ve Türkçe konusunda yetkin her iki dilin de yapısını bilen dört akademisyen ile COVID-19 ve ölçek geliştirme konusunda çalışmaları olan yetkin kendi alanındaki kavramları iyi bilen üç akademisyenin ortak çabası ile ölçek Türkçe'ye çevrilmiştir. Orijinal ölçek, 5 faktör ve 16 maddeden oluşmaktadır. Ölçeğin "Klinik Sunumlar" birinci boyutunda 4 soru (K1-K4); "Bulaşma Yolları" ikinci boyutunda 3 soru (K5-K7); "Önleme ve Kontrol” üçüncü boyutunda 5 soru (K8-K12); "Tutumlar" dördüncü boyutunda 2 soru (A1-A2); "Davranış" beșinci boyutunda 2 soru (P1-P2) bulunmaktadır. COVID-19’a Yönelik Bilgi, Tutum ve Davranış Ölçeği için AFA analizi yürütülmüştür. AFA sonucuna göre 16 maddelik olan COVID-19'a Yönelik Bilgi, Tutum ve Davranış Ölçeğinin tıpkı Zhong ve ark. tarafından geliştirilmiş olan orijinalinde (6) olduğu gibi beş alt boyutta yer aldığı tespit edilmiştir. AFA sonuçlarına göre ortaya çıkan beş boyutlu yapı, toplam varyansın \% 60,208'ini açıklamaktadır. Açıklanan varyansın sosyal bilimlerdeki çalışmalar için \%40 ve üstü olması ölçeğin güçlülügünü göstermektedir ki bu çalışma için elde edilen varyansın yaklaşık olarak \%60 olması ölçeğin güçlü olduğunu göstermektedir. AFA sonuçlarına göre elde edilen faktör yüklerinin, eşik değer olarak kabul edilen 0,50'nin üzerinde olduğu görülmektedir (Tablo 1). Örneklem büyüklüğüne olan bağımlılı̆̆ın bir sonucu olarak, farklı araştırmacılar 2 ile 5 arasındaki değerin makul bir uyumu belirtmek için yeterli olduğunu ifade etmektedir (15). DFA sonuçlarına ilişkin Tablo 2 incelendiğinde; $\chi 2$ değerinin istatistiksel olarak anlamlı olduğu $(\chi 2 / s d=2,840$; $\mathrm{p}<0,001)$ görülmüştür.

Türkçe Geçerlik ve Güvenirlik yapılan bu çalışma orijinal çalışmada olduğu gibi 3 faktörlü yapı ile AFA ve DFA analizleri yapılmıştır. Daha sonra yine orijinal çalışmada olduğu gibi dikotom verilere sahip olan iki faktör ise analize dâhil edilmeyip sonradan ölçeğe eklenmiştir. Bu ölçeği kullanacak olan araştırmacıların, 5 faktörün tamamını çalışmalarında kullanması gerekmektedir.

COVID-19'a Yönelik Bilgi, Tutum ve Davranış Ölçeğinin güvenirlik analizi için bakılan Cronbach Alpha değerleri birinci faktör için 0,785 , ikinci faktör için 0,782 , üçüncü faktör için 0,734 , dördüncü faktör için 0,712 , beşinci faktör için 0,723 ve son olarak toplam ölçek için 0,747 olarak bulunmuştur. Elde edilen veriler işığında ölçeğin oldukça güvenilir olduğu ifade edilebilir.

Yapılan analizlerin sonucunda, COVID-19'a Yönelik Bilgi, Tutum ve Davranış Ölçeğinin güvenilir ve geçerli bir ölçek olduğu tespit edilmiştir.

Teşekkür

Çalışmaya gönüllü olarak katılan tüm katılımcılara teşekkür ederiz.

\section{Yazarların Makaleye Katkı Beyanı}

Çalışma konusunun belirlenmesi ve literatür taraması: Cuma Çakmak, Çalışma istatistiğinin değerlendirilmesi ve çalışmanın son gözden geçirilmesi süreci: Haşim Çapar, Çalışmanın ve anketlerin düzenlenmesi ve istatistik çalı̧̧maların yapılmass: İsmail Biçer, Anketlerin yapılması, çalışmanın yazım aşamasında literatür araştırması ve çalışmanın tartışma kısmının yazımı Halil Demir ve Mehmet Emin Kurt tarafından yapılmıştır. 


\section{Finansal Destek}

$\mathrm{Bu}$ makale ile ilgili herhangi bir finansal kaynaktan yararlanılmamiştır.

\section{Etik Kurul Onayı}

Araştırmada Sağlık Bakanlığı Bilimsel Araştırma Platformundan ve İstanbul Arel Üniversitesi Girişimsel Olmayan Etik Kurulundan 09.07.2020 tarih ve 2020/04 sayı ile etik kurul onayı alınmıştır. Araştırma 15 Temmuz-15 Ağustos 2020 tarihleri arasında gerçekleştirilmiştir.

\section{Çıkar Çatışması}

Bu makale ile ilgili herhangi bir çıkar çatışması bulunmamaktadır.

\section{Hakemlik Süreci}

Kör hakemlik süreci yayınlanmaya uygun bulunmuş ve karar verilmiştir.

\section{KAYNAKLAR}

1. Sağlık Bakanlığı (2020). https://COVID19.saglik.gov.tr/ Eklenti/38597/0/COVID-19rehberigenelbilgilerepidemiyolo jive tanipdf.pdf, Türkiye Cumhuriyeti Sağlık Bakanlığı, Halk Sağlı̆̆ı Genel Müdürlüğü, COVID-19 Rehberi, Genel Bilgiler Epidemiyolojı ve Tanı Bölümü, s;5-6, Güncellenme Tarihi: 3.09.2020

2. Ajilore K, Atakiti I, Onyenankey K. College students' knowledge, attitudes and adherence to public service announcements on Ebola in Nigeria: Suggestions for improving future Ebola prevention education programmes. Health Education Journal. 2017;76:648-660.

3. Tachfouti N, Slama K, Berraho M, Nejjari C. The impact of knowledge and attitudes on adherence to tuberculosis treatment: A case-control study in a Moroccan region. Pan Afr Med J. 2012; 12: 52.
4. Person B, Sy F, Holton K, Govert B, Liang A. National Center for Inectious Diseases/ SARS Community Outreach Team. Fear and stigma: The epidemic within the SARS outbreak. Emerg Infect Dis. 2004;10:358-363.

5. Tao N. An analysis on reasons of SARS-induced psychological panic among students. Journal of Anhui Institute of Education. 2003; 6: 78-79.

6. Zhong BL, Luo W, Li HM, Qian-Qian Zhang QQ, Liu XG, Li WT, Li Y. Knowledge, attitudes, and practices towards COVID-19 among Chinese residents during the rapid rise period of the COVID-19 outbreak: A quick online crosssectional survey. Int J Biol Sci. 2020; 16(10): 1745-1752.

7. Gılıç E, Ceyhan O, Özer A. Niğde Doğumevi'nde doğum yapan kadınların aile planlaması konusundaki bilgi tutum ve davranışları. Fırat Tıp Dergisi. 2009;14(4): 237-241.

8. Anderson JC, Gerbing DW. Structural equation modeling in practice: A review and recommended two-step approach. Psychological Bulletin. 1988;103(3):411-423.

9. Ford JK, MacCallum RC, Tait M. The application of exploratory factor analysis in applied psychology: A critical review and analysis. Personnel Psychology. 1986;39(2):291-314.

10. George D, Mallery P. SPSS for windows. Needham Heights, MA: A Pearson Education. 2001.

11. Tavşancıl E. Tutumların ölçülmesi ve SPSS ile veri analizi. (3. Baskı). Ankara: Nobel Yayın Dağıtım. 2006.

12. Hair JF, Black WC, Babin BJ, Anderson RE, Tatham RL. Multivariate data analysis. Upper Saddle River, NJ: Prentice Hall. 1998.

13. Anderson JC, Gerbing DW. Structural equation modeling in practice: A review and recommended two-step approach. Psychological Bulletin. 1988;103(3):411.

14. Tabachnick BG, Fidell LS. Using Multivariate Statistics (Sixth Edition), Pearson, 2014.

15. Marsh HW, Hocevar D. Application of confirmatory factor analysis to the study of self-concept: First-and higher order factor models and their invariance across groups. Psychological Bulletin. 1985;97(3):562. 